\title{
Front Matter: Volume 10208
}

, "Front Matter: Volume 10208," Proc. SPIE 10208, Fiber Optic Sensors and Applications XIV, 1020801 (5 June 2017); doi: 10.1117/12.2270684

SPIE Event: SPIE Commercial + Scientific Sensing and Imaging, 2017, Anaheim, SPIE. CA, United States 


\title{
PROCEEDINGS OF SPIE
}

\section{Fiber Optic Sensors and Applications XIV}

\author{
Christopher S. Baldwin \\ Gary Pickrell \\ Henry H. Du \\ Eric Udd \\ Jerry J. Benterou \\ Anbo Wang \\ Editors
}

11-12 April 2017

Anaheim, California, United States

Sponsored and Published by

SPIE 
The papers in this volume were part of the technical conference cited on the cover and title page. Papers were selected and subject to review by the editors and conference program committee. Some conference presentations may not be available for publication. Additional papers and presentation recordings may be available online in the SPIE Digital Library at SPIEDigitallibrary.org.

The papers reflect the work and thoughts of the authors and are published herein as submitted. The publisher is not responsible for the validity of the information or for any outcomes resulting from reliance thereon.

Please use the following format to cite material from these proceedings:

Author(s), "Title of Paper," in Fiber Optic Sensors and Applications XIV, edited by Christopher S. Baldwin, Gary Pickrell, Henry H. Du, Eric Udd, Jerry J. Benterou, Anbo Wang, Proceedings of SPIE Vol. 10208 (SPIE, Bellingham, WA, 2017) Seven-digit Article CID Number.

ISSN: 0277-786X

ISSN: 1996-756X (electronic)

ISBN: 9781510609174

ISBN: 9781510609181 (electronic)

Published by

SPIE

P.O. Box 10, Bellingham, Washington 98227-0010 USA

Telephone +1 3606763290 (Pacific Time) · Fax +1 3606471445

SPIE.org

Copyright @ 2017 , Society of Photo-Optical Instrumentation Engineers.

Copying of material in this book for internal or personal use, or for the internal or personal use of specific clients, beyond the fair use provisions granted by the U.S. Copyright Law is authorized by SPIE subject to payment of copying fees. The Transactional Reporting Service base fee for this volume is $\$ 18.00$ per article (or portion thereof), which should be paid directly to the Copyright Clearance Center (CCC), 222 Rosewood Drive, Danvers, MA 01923. Payment may also be made electronically through CCC Online at copyright.com. Other copying for republication, resale, advertising or promotion, or any form of systematic or multiple reproduction of any material in this book is prohibited except with permission in writing from the publisher. The CCC fee code is $0277-786 \mathrm{X} / 17 / \$ 18.00$.

Printed in the United States of America.

Publication of record for individual papers is online in the SPIE Digital Library.

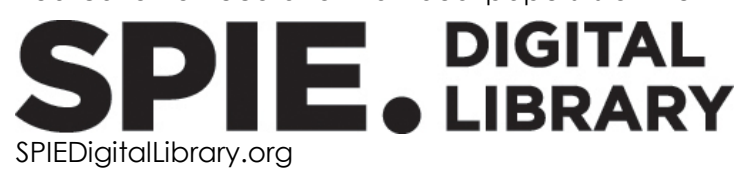

Paper Numbering: Proceedings of SPIE follow an e-First publication model. A unique citation identifier (CID) number is assigned to each article at the time of publication. Utilization of CIDs allows articles to be fully citable as soon as they are published online, and connects the same identifier to all online and print versions of the publication. SPIE uses a seven-digit CID article numbering system structured as follows:

- The first five digits correspond to the SPIE volume number.

- The last two digits indicate publication order within the volume using a Base 36 numbering system employing both numerals and letters. These two-number sets start with 00, 01, 02, 03, 04, 05, 06, 07, 08, 09, OA, OB ... OZ, followed by 10-1Z, 20-2Z, etc. The CID Number appears on each page of the manuscript. 


\title{
Contents
}

\author{
vii Authors \\ ix Conference Committee
}

\section{SESSION 1 FIBER OPTIC SENSING FOR AEROSPACE}

1020802 Mars or bust! 40 years of fiber optic sensor development (Invited Paper) [10208-1]

1020803 Optical frequency domain reflectometry for aerospace applications [10208-2]

1020805 Improvement of the extinction ratio performance of a fiber laser based rangefinder by using successive real-time statistical algorithms [10208-4]

\section{SESSION 2 INTERFEROMETRIC AND GYROSCOPE SENSORS}

1020806 Modeling of thermal sensitivity of a fiber optic gyroscope coil with practical quadrupole winding [10208-5]

1020807 Fiber optic gyroscope coils: performance characterization [10208-6]

1020808 An interferometric sensor based on visibility modulation [10208-7]

SESSION 3 NEW AVENUES IN FIBER OPTIC SENSING

10208 OA Improvement of light confinement in nanostructured sapphire optical fibers [10208-9]

10208 OC Modified single crystal fibers for distributed sensing applications [10208-11]

10208 OD Simultaneous transmission of the high-power phase sensitive OTDR, 100Gbps dual polarisation QPSK, accurate time/frequency, and their mutual interferences [10208-13]

SESSION 4 DISTRIBUTED FIBER OPTIC SENSING

10208 OE SNR improvement in a Raman based distributed temperature sensing system using a stimulated Raman scattering filter [10208-14]

10208 OG Deep learning based multi-threat classification for phase-OTDR fiber optic distributed acoustic sensing applications [10208-16]

10208 ol Fiber optic sensors for distributed monitoring of soil and groundwater during in-situ thermal remediation [10208-41] 
$10208 \mathrm{OJ} \quad$ Adapting optical technology to dynamic energy prices: fiber-optic sensing in the contemporary oil field (Invited Paper) [10208-18]

10208 OK The evolution of optical fiber cable design for sensor applications [10208-19]

$10208 \mathrm{OL}$ In-situ Raman investigation of optical fiber glass structural changes at high temperature [10208-20]

10208 OM Relative acoustic sensitivity of standard telecom and specialty optical fiber cables for distributed sensing [10208-22]

10208 ON Applications of fiber optic sensors for heavy oil production [10208-23]

SESSION 6 FIBER BRAGG GRATING SENSORS

$1020800 \quad$ Ultrafast photonic systems for FBG sensing in detonation and shock wave experiments (Invited Paper) [10208-24]

10208 OP Optimization of fiber Bragg grating parameters for sensing applications (Invited Paper) [10208-25]

$102080 Q \quad$ Force and pressure sensing using fiber grating sensors [10208-26]

10208 OR Performance assessment of a fiber Bragg grating sensor network inside a hydro power dam using optical backscatter reflectometry [10208-27]

10208 OT Design, implementation, and characterization of an FBG-emulator for a scanning laserbased fiber-optic interrogator [10208-29]

\section{POSTER SESSION}

$10208 \mathrm{OU} \quad$ Influence of different encapsulation types and shapes of polydimethylsiloxane on the temperature sensitivity of the FBG [10208-30]

10208 OV Impact of fixing materials on the frequency range and sensitivity of the fiber-optic interferometer [10208-31]

10208 OW Fiber optic sensor encapsulated in polydimethylsiloxane for heart rate monitoring [10208-32]

10208 OX Analysis of the impact of the deposition optical fibers on the deformation measurement with a distributed system BOTDR [10208-33]

$102080 Z$ Research on an optimized optical fiber accelerometer for well logging [10208-35]

1020810 Real-time phase demodulation and data administration of distributed optical fiber vibration sensing system [10208-37] 
1020811 Numerical analysis of a new sensing composite structure embedding optical fiber [10208-36]

1020812 The influence of temperature loading on the optical fiber passive components [10208-38]

1020813 Various optical fibers fixing methods for mechanical stress measurements [10208-39]

1020814 Masonry moisture measurement using the distributed temperature sensing system [10208-40] 
Proc. of SPIE Vol. 10208 1020801-6

Downloaded From: https://www.spiedigitallibrary.org/conference-proceedings-of-spie on 26 Apr 2023 Terms of Use: https://www.spiedigitallibrary.org/terms-of-use 


\section{Authors}

Numbers in the index correspond to the last two digits of the seven-digit citation identifier (CID) article numbering system used in Proceedings of SPIE. The first five digits reflect the volume number. Base 36 numbering is employed for the last two digits and indicates the order of articles within the volume. Numbers start with 00, 01, 02, 03, 04, 05, 06, 07, 08, 09, OA, OB...0Z, followed by 10-12, 20-2Z, etc.

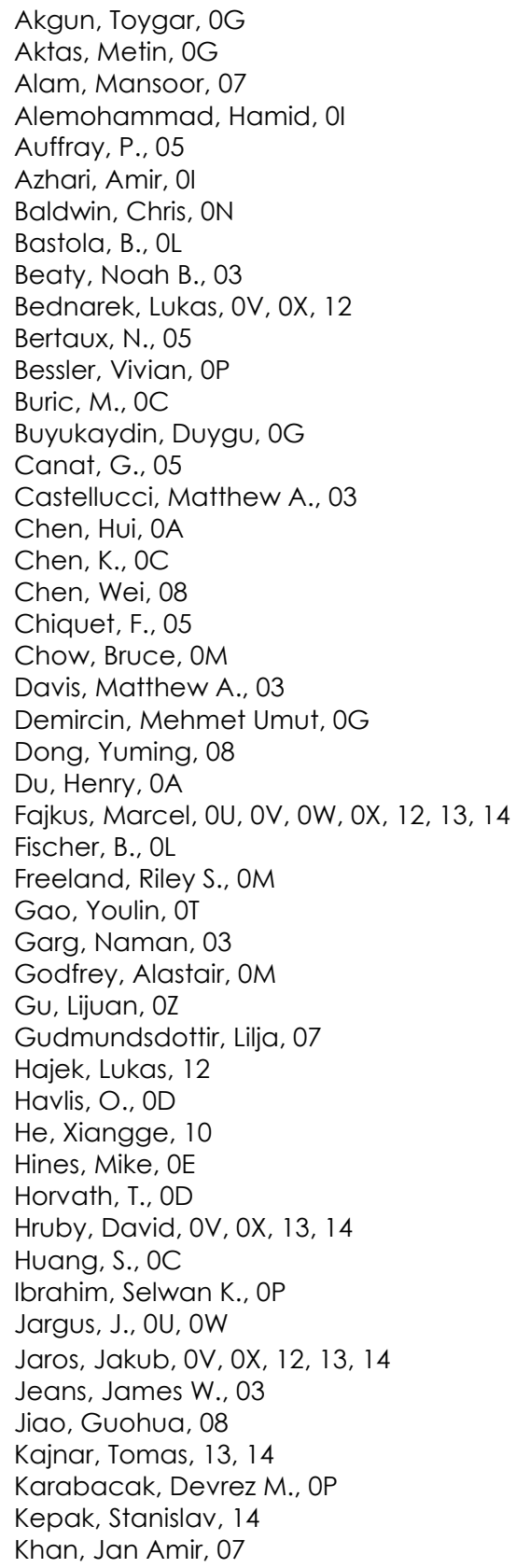

Klug, Ferdinand, $O R$

Koch, Alexander W., OT

Kominski, Dan, 03

Kreger, Stephen T., 03

Kuhenuri, Nader, OT

Le Flohic, M., 05

$\mathrm{Li}$, Jie, OE

Liang, Richard, $\mathrm{Ol}$

Lienhart, Werner, OR

Liv, B., OC

Liu, Fei, 10

LU, P., OC

Lu, Yuanfu, 08

LV, Jiancheng, 08

Maida, John L., OJ

Martinek, Radek, OU, OV, OW, OX

Monsberger, Christoph, OR

Munster, P., OD

Nedoma, Jan, OU, OV, OW, OX, 12, 13, 14

Novak, M., OU, OW

O'Dowd, John A., OP

Ogut, Serdar, 06

Ohanian, Osgar John III, 03

Ohodnicki, Paul, OA, OC

Osunluk, Berk, 06

Ozbay, Ekmel, 06

Pallier, G., 05

Pedrazzani, J. R., 03

Perecar, Frantisek, OU, OX, 12, 13, 14

Poole, Zsolt L., OA

Portalis, A., 05

Qin, Mengzhe, 10

Qiu, Xiaokang, $\mathrm{OZ}$

Radil, J., OD

Rahim, Nur Aida Abdul, 03

Rodriguez, George, 00

Roths, J., OL

Ruediger, A., OL

Singer, Johannes M., OP

Skaljo, E., OD

Skinner, Neal G., OJ

Smotlacha, V., OD

Stark, Daniel J., OJ

Sun, Xiaoguang, OE

Templeton, Emily H., 03

Udd Scheel, Ingrid, $02,0 Q$

Udd, Eric, 02, OQ

Vanderka, Ales, 12

Vasinek, Vladimir, OU, OV, OW, OX, 12, 13, 14 
Vojtech, J., OD

Wang, M., OC

Williams, John, OM

Witas, K., OU

Yamasaki, Dean J., OK

Yang, Jianming, 11

Yi, Duo, 0Z, 11

Yu, Wenhui, 11

Zabka, Stanislav, OV

Zboril, O., OU

Zhang, Liang, 08

Zhang, Min, OZ, 10, 11

Zheng, Xiaoping, 10

Proc. of SPIE Vol. 10208 1020801-8

Downloaded From: https://www.spiedigitallibrary.org/conference-proceedings-of-spie on 26 Apr 2023 Terms of Use: https://www.spiedigitallibrary.org/terms-of-use 


\title{
Conference Committee
}

\author{
Symposium Chair
}

Majid Rabbani, Rochester Institute of Technology (United States)

Symposium Co-chair

Robert Fiete, Harris Corporation (United States)

Conference Chairs

Christopher S. Baldwin, Weatherford International Ltd. (United States)

Gary Pickrell, Virginia Tech (United States)

Henry H. Du, Stevens Institute of Technology (United States)

Conference Co-chairs

Eric Udd, Columbia Gorge Research (United States)

Jerry J. Benterou, Lawrence Livermore National Laboratory (United States)

Anbo Wang, Virginia Polytechnic Institute and State University (United States)

Conference Program Committee

Ole Bang, Danmarks Tekniske Universitet (Denmark)

Eric A. Bergles, BaySpec Inc. (United States)

Kevin Peng Chen, University of Pittsburgh (United States)

Brian Culshaw, University of Strathclyde (United Kingdom)

Sachin Dekate, GE Global Research (United States)

Abdessama Elyamani, Northrop Grumman Navigation Systems (United States)

Xudong Fan, University of Michigan (United States)

Yoel Fink, Massachusetts Institute of Technology (United States)

Todd C. Haber, Micron Optics, Inc. (United States)

Ming Han, University of Nebraska-Lincoln (United States)

Hajime Haneda, National Institute for Materials Science (Japan)

Daniel Homa, Virginia Polytechnic Institute and State University (United States)

Kazuo Hotate, The University of Tokyo (Japan)

Jiri Kanka, Institute of Photonics and Electronics of the ASCR, v.v.i. (Czech Republic)

Gurbinder Kaur, Thapar University (India)

Victor I. Kopp, Chiral Photonics, Inc. (United States) 
Katerina Krebber, Bundesanstalt für Materialforschung und -prüfung (Germany)

Stephen T. Kreger, Luna Innovations Inc. (United States)

David A. Krohn, Light Wave Venture Consulting, LLC (United States)

John L. Maida Jr., Halliburton (United States)

Alexis Mendez, MCH Engineering LLC (United States)

Stephen J. Mihailov, National Research Council Canada (Canada)

Thomas D. Monte, KVH Industries, Inc. (United States)

Glen A. Sanders, Honeywell Technology (United States)

Jasbinder S. Sanghera, U.S. Naval Research Laboratory (United States)

Fei Tian, Stevens Institute of Technology (United States)

Dennis J. Trevor, OFS Laboratories (United States)

Xingwei Wang, University of Massachusetts Lowell (United States)

Reinhardt Willsch, Institut für Photonische Technologien e.V. (Germany)

Hai Xiao, Clemson University (United States)

Yizheng Zhu, Virginia Polytechnic Institute and State University

(United States)

\section{Session Chairs}

1 Fiber Optic Sensing for Aerospace

Eric Udd, Columbia Gorge Research LLC (United States)

Stephen T. Kreger, Luna Innovations Inc. (United States)

2 Interferometric and Gyroscope Sensors

Ingrid Udd Scheel, Multnomah Falls Research LLC (United States)

Fei Tian, Stevens Institute of Technology (United States)

3 New Avenues in Fiber Optic Sensing

Gary Pickrell, Virginia Tech (United States)

Henry Du, Stevens Institute of Technology (United States)

4 Distributed Fiber Optic Sensing

Christopher S. Baldwin, Weatherford International Ltd. (United States)

Xiaoguang Sun, OFS (United States)

5 Applications of Fiber Optic Sensors for Harsh Environments

Christopher S. Baldwin, Weatherford International Ltd. (United States)

John L. Maida Jr., Halliburton (United States)

6 Fiber Bragg Grating Sensors

Alexis Mendez, MCH Engineering LLC (United States)

George Rodriguez, Los Alamos National Laboratory (United States) 